\title{
Rag2-deficient IL-1 Receptor Antagonist-deficient Mice Are a Novel Colitis Model in Which Innate Lymphoid Cell-derived IL-17 Is Involved in the Pathogenesis
}

\author{
Aoi AKITSU1, 2, 3), Shigeru KAKUTA ${ }^{1,4)}$, Shinobu SAIJO ${ }^{1,5)}$ and Yoichiro IWAKURA ${ }^{1,2,3)}$ \\ 1) Center for Experimental Medicine and Systems Biology, The Institute of Medical Science, The University of Tokyo, \\ 4-6-1, Shirokanedai, Minato-ku, Tokyo 108-8639, Japan \\ 2) Department of Biophysics and Biochemistry, Graduate School of Science, The University of Tokyo, Tokyo 113-0032, \\ Japan \\ ${ }^{3)}$ Research Institute for Biomedical Sciences, Tokyo University of Science, Chiba 278-0022, Japan \\ 4) Present address: Department of Biomedical Science, Graduate School of Agricultural and Life Sciences, The \\ University of Tokyo, Tokyo 113-8657, Japan \\ 5) Present address: Department of Molecular Immunology, Medical Mycology Research Center, Chiba University, \\ Chiba 263-8522, Japan
}

\begin{abstract}
: $/ / 1 \mathrm{rn}^{-1-}$ mice spontaneously develop arthritis and aortitis by an autoimmune mechanism and also develop dermatitis by an autoinflammatory mechanism. Here, we show that $\mathrm{Rag}^{-1-} \mid l 1 \mathrm{rn}^{-1-}$ mice develop spontaneous colitis with high mortality, making a contrast to the suppression of arthritis in these mice. Enhanced IL-17A expression in group 3 innate lymphoid cells (ILC3s) was observed

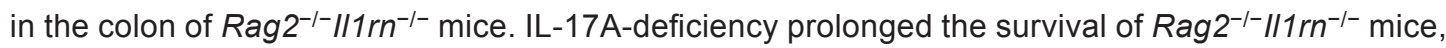
suggesting a pathogenic role of this cytokine in the development of intestinal inflammation. Although IL-17A-producing T cells were increased in $/ 11 \mathrm{rn}^{-1-}$ mice, these mice did not develop colitis, because $\mathrm{CD} 4^{+} \mathrm{Foxp}^{+}{ }^{+}$regulatory $\mathrm{T}$ cell population was also expanded. Thus, excess IL-1 signaling and IL-1-

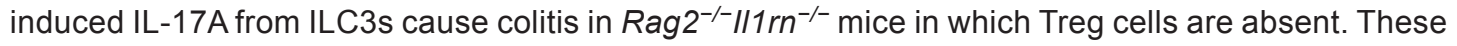
observations suggest that the balance between IL-17A-producing cells and Treg cells is important to keep the immune homeostasis of the colon.
\end{abstract}

Keyword: Colitis, IL-1, IL-17, innate lymphoid cells, regulatory Tcells

\section{Introduction}

Inflammatory bowel disease (IBD) is a chronic inflammatory disease of the gastrointestinal tract, characterized by both intestinal inflammation and mucosal tissue destruction [15, 35]. Although the etiopathogenesis of IBD is not completely understood, an excessive host immune response against intestinal commensal microbiota is suggested to be involved in the disease development.
Interleukin-17A (IL-17A) is implicated in the development of inflammatory diseases, such as IBD, rheumatoid arthritis and psoriasis, by inducing proinflammatory cytokines and chemokines, recruiting neutrophils, and activating $\mathrm{T}$ cells and $\mathrm{B}$ cells [14]. In line with this notion, IL-17A expression is increased in the mucosa and serum in IBD patients [8]. Although $\mathrm{CD}^{+}$Th17 cells are well-known IL-17A producers responsible for the development of inflammatory diseases, the contribution

(Received 6 December 2013 / Accepted 10 December 2013)

Address corresponding: Y. Iwakura, Center for Animal Disease Models, Research Institute for Biomedical Sciences, Tokyo University of Science, Yamazaki 2669, Noda-shi, Chiba 278-0022, Japan

(C2014 Japanese Association for Laboratory Animal Science 
of Th17 cells in intestinal inflammation is controversial [24]. Recent studies have shown that the majority of IL-17A is derived from innate-like or innate immune cells in inflammatory sites, especially in gut mucosal tissues [4]. Indeed, intestinal inflammation in many of IBD models develops in immunodeficient mice lacking adaptive immunity [2, 26, 33]. Moreover, the pathogenic role of innate immune cell-derived IL-17A has been directly demonstrated using Helicobacter hepaticus (H. hepaticus)-infected 129SvEvRag $2^{-/-}$mice [2].

$\gamma \delta \mathrm{T}$ cells and group 3 innate lymphoid cells (ILC3s) share many characteristics with Th17 cells. These cells can produce IL-17A and IL-22 immediately after stimulation without further differentiation, because these cells constitutively express orphan nuclear receptor ROR $\gamma \mathrm{t}$ and signature cytokine receptor IL-23R [31, 32]. IL-1 $\beta$ and IL-23 stimulation induces IL-17A in the absence of TCR signaling in these cells [3, 31]. Thus, both types of cells contribute to host defense in the early phase after infection.

$\gamma \delta \mathrm{T}$ cells are shown to induce intestinal inflammation in colitis models $[6,23,25]$. ILC3s are a recently identified leukocyte lineage marker negative $\left(\mathrm{Lin}^{-}\right)$and ROR $\gamma \mathrm{t}^{+}$cell population with CD4 ${ }^{-}$Thy $1.2^{\text {hi }} \mathrm{Sca}^{-{ }^{+}}{ }^{\mathrm{c}}$-kit ${ }^{-}$ markers [30], and ILC3-derivrd IL-17A is suggested to be involved in the pathogenesis of colitis. In H. hepaticus-infected colitis model, IL-17A production from ILC3s causes colonic inflammation in response to bacteria-induced IL-23 [2]. In addition, IL-17A production from ILC3s can induce spontaneous colitis in $T b \times 21^{-/-}$ Rag $2^{-/-}$mice [26]. However, the in vivo mechanism of IL-17A production from these cells and that of disease development remain to be elucidated.

IL- $1 \beta$ is a proinflammatory cytokine that causes various inflammatory responses in both innate and adaptive immunity. IL- $1 \beta$ induces the expansion and the maintenance of Th17 cells [14] and also activates $\gamma \delta$ T cells and ILCs to produce IL-17A in collaboration with IL-23 [29, 32]. IL-1 receptor antagonist (IL-1Ra, gene symbol: Illrn) is an endogenous IL-1 inhibitor, which competes with IL- $1 \alpha$ and IL- $1 \beta$ for IL-1 receptor (IL-1R) binding. We previously showed that IL-1Ra-deficient $\left(\mathrm{Ill} \mathrm{rr}^{-/-}\right)$ mice on BALB/cA background spontaneously develop inflammatory diseases, such as arthritis [13], aortitis [19], and dermatitis [22], indicating that strict regulation of IL-1 activity is critical for immune homeostasis. Using cytokine-deficient mice and adoptive cell transfer, we demonstrated that arthritis and aortitis develop by a
T cell-dependent autoimmune mechanism whereas dermatitis is caused by a $T$ cell-independent autoinflammatory mechanism $[12,19,22]$. Moreover, TNF- $\alpha$ deficiency restrains the development of both arthritis and dermatitis, whereas IL-17A deficiency does not suppress dermatitis development. Thus, $I l 1 \mathrm{rn}^{-/-}$mice are a unique inflammatory disease model in which both adaptive and innate immune cell-mediated inflammatory responses are observed.

In this report, we show that $\mathrm{Rag} 2^{-/} \mathrm{IlIrn}^{-/-}$mice develop spontaneous severe colitis with high mortality, making a contrast to the suppression of arthritis in these mice. Enhanced IL-17A expression in ILC3s was observed in the colon of $\mathrm{Rag}^{-/-} \mathrm{Ill} \mathrm{rn}^{-/}$mice and IL-17A deficiency prolonged the survival of $\mathrm{Rag}^{-/-} \mathrm{Ill} \mathrm{rn}^{-/-}$ mice, suggesting a pathogenic role of this cytokine in the exacerbation of intestinal inflammation. Because $\mathrm{Rag}^{-/-} I l 1 \mathrm{rn}^{-/-}$mice, in which Foxp $3^{+}$Treg cells were absent and ILC3s were expanded, developed colitis, but $I l 1 \mathrm{rn}^{-/-}$mice, in which Treg cell population was increased, did not develop colitis in spite of the expansion of IL-17A-producing $\mathrm{T}$ cells, it is suggested that the balance between IL-17A-producing cells and Treg cells is important for the homeostasis of intestinal immunity.

\section{Materials and Methods}

Mice

$\mathrm{BALB} / \mathrm{cA}$ genetic background mice were used throughout this study. BALB/cA and nu/nu mice were purchased from CLEA Japan. $I l 1 \mathrm{rn}^{-/}$mice were produced as described [11]. nu/nuIll $\mathrm{rn}^{-/-}$mice were produced by crossing $I l l \mathrm{rn}^{-/-}$mice with $n u / n u$ mice (CLEA Japan). $\operatorname{Rag} 2^{-1-}$ mice were a gift from Dr. Sakaguchi (Osaka University, Japan) [10]. Rag $2^{-/-}$mice were crossed to $\mathrm{Ill} \mathrm{rn}^{-/-}$mice to generate $\mathrm{Rag}^{-/-} \mathrm{Ill} \mathrm{rn}^{-/}$mice, $I l 17 a^{-/-} I l 1 \mathrm{rn}^{-/-}$mice were generated as described [21] and were crossed to $\mathrm{Rag} 2^{-/-} I l 1 \mathrm{rn}^{-/-}$mice to generate Ill $7 \mathrm{a}^{-/-} \mathrm{Rag}^{-1-} \mathrm{Il}_{1 \mathrm{rn}^{-1-}}$ mice. Age-matched and sexmixed mice were used for all experiments, except Fig. 4 , in which only females were used. All mice were kept under specific pathogen-free conditions in environmentally controlled clean rooms at the Center for Experimental Medicine and Systems Biology, The Institute of Medical Science, The University of Tokyo, and Institute for Biomedical Sciences, Tokyo University of Science. All experiments were approved by the institutional ethical committees for animal experiments and the com- 
mittees for gene manipulation experiments.

\section{Histologic analysis of the colon}

Colon tissues were removed from mice at 10 -weeks of age, and paraffin sections were made and stained with hematoxyslin and eosin.

\section{Isolation of LP cells in the colon}

LP cells were isolated from the colon as described [34] with modifications. Briefly, colon tissues were removed from mice and cut into $1 \mathrm{~cm}$ pieces, and incubated in RPMI medium (Sigma, St. Louis, MO, USA) containing $10 \%$ heat-inactivated FCS and $5 \mathrm{mM}$ EDTA to remove epithelial cells. The remaining tissues were further digested with RPMI medium containing 10\% FCS, $5 \mathrm{mM}$ EDTA, and $200 \mathrm{U} / \mathrm{ml}$ collagenase (Sigma). LP cells were then layered on a $75 \%$ Percoll gradient (Sigma), and after centrifugation at 2,200 rpm for $20 \mathrm{~min}$, cells were collected at the $40 \% / 75 \%$ Percoll interface.

\section{Flow cytometry}

Intracellular cytokine staining was performed as described previously [16] after stimulation with $50 \mathrm{ng} / \mathrm{ml}$ PMA (Sigma), $500 \mathrm{ng} / \mathrm{ml}$ ionomycin (Sigma), and $2 \mu \mathrm{M}$ monensin (Sigma) for $5 \mathrm{~h}$. For cell surface molecule staining, cells were first treated with anti-mouse CD16/ CD32 mAbs (2.4G2, purified from hybridoma culture supernatant) in staining buffer (HBSS containing 2\% FCS and $0.1 \%$ sodium azide) to block FcR binding, then cells were stained with the following antibodies: PEanti-mouse $\gamma \delta$ TCR mAbs (GL3; BioLegend, San Diego, CA, USA), PE-anti-mouse Ly6A/E (Sca-1) mAbs (D7; eBioscience, San Diego, CA, USA), PE/Cy7-anti-mouse CD4 mAbs (GK1.5; BioLegend), APC-anti-mouse CD $8 \alpha$ mAbs (53-6.7; BioLegend), APC-anti-mouse CD335 (NKp46) mAbs (29A1.4; BioLegend), APC/Cy7-antimouse CD3 $\varepsilon$ mAbs (145-2C11; BioLegend), Pacific Blue-anti-mouse CD90.2 (Thy1.2) mAbs (30-H12; BioLegend), Pacific Blue-anti-mouse CD117 (c-kit) mAbs (2B8; BioLegend). For the analysis of leukocyte lineage marker negative cells, cells were stained with the following antibodies: FITC-anti-mouse CD4 mAbs (GK1.5; BioLegend), FITC-anti-mouse CD8 mAb (53-6.7; BioLegend), FITC-anti-mouse $\gamma \delta$ TCR mAbs (GL3; eBioscience), FITC-anti-mouse CD11b mAbs (M1/70; BioLegend), FITC-anti-mouse CD11c mAbs (HL3; BD Permingen), FITC-anti-mouse Gr-1 mAbs (RB6-8C5; BioLegend), FITC-anti-mouse B220 mAbs (RA-3-6B2;
BioLegend). Then, cells were fixed with $4 \%$ paraformaldehyde. For intracellular cytokine staining, cells were treated with a permeabilization buffer $(0.1 \%$ saponin [Sigma] in staining buffer), and incubated with the following antibodies: FITC-anti-mouse IFN- $\gamma$ mAbs (XMG1.2; eBioscience), FITC-anti-mouse IL-10 mAbs (JES5-16E3; BioLegend), and Pacific Blue-anti-mouse IL-17A mAbs (TC11-18H10.1; BioLegend). Intranuclear staining was performed with Foxp3 Staining Kit according to the manufacturer's instructions (eBioscience) with the following antibodies: PE-anti-mouse Foxp3 mAbs (FJK-16s; eBioscience) and APC-anti-mouse ROR $\gamma \mathrm{t}$ mAbs (AFKJS-9; eBioscience). 7-Aminoactinomycin D (Sigma) was used for staining dead cells. Cells were analyzed on a FACSCantoII system (Becton Dickinson, Franklin Lakes, NJ, USA) and data were analyzed with FlowJo software (Tree Star).

\section{Real-time PCR}

Total RNA from anal and colon was extracted with Sepasol reagent (Nacalai Tesque, Kyoto, Japan) according to the manufacturer's instructions and was denatured in the presence of an oligo dT primer and then reverse transcribed with the High Capacity cDNA Reverse Transcription Kit (Applied Biosystems, Foster City, CA, USA). Quantitative real time PCR was performed with a SYBR Green qPCR kit (Invitrogen, Carlsbad, CA, USA) and an iCycler system (Bio-Rad, Hercules, CA, USA) with the sets of the following primers:

Gapdh 5'-TTC ACC ACC ATG GAG AAG GC-3' and 5'-GGC ATG GAC TGT GGT CAT GA-3'; Il17a 5'-TTT AAC TCC CTT GGC GCA AAA-3' and 5'-CTT TCC CTC CGC ATT GAC AC-3'; Ill $7 f$ 5'-TGC TAC TGT TGA TGT TGG GAC-3' and 5'-AAT GCC CTG GTT TTG GTT GAA-3'; Ifng 5'-GAA CTG GCA AAA GGA TGG TGA-3' and $5^{\prime}$-TGT GGG TTG TTG ACC TCA AAC-3'; Ill 5'-GGT CTC AAC CCC CAG CTA GT-3' and 5'-GCC GAT GAT CTC TCT CAA GTG AT-3'; Illa 5'-TCG GGA GGA GAC GAC GAC TCT AA-3' and 5'-TGT TTC TGG CAA TCC TTC A-3'; Illb 5'-CAA CCA ACA AGT GAT ATT CTC CAT G-3' and 5'-GAT CCA CAC TCT CCA GCT GCA-3'; Illrn 5'-AAA TGG CAG TCG CTA GTC TCT ATT-3' and 5'-AGAATC CCA GAT TCT GAA GGC TTG C-3'; Il22 5'-TGA CGA CCA GAA CAT CCA GA- $3^{\prime}$ and $5^{\prime}$-AGC TTC TTC TCG CTC AGA CG-3'; Ill2p40 5'-TGG TTT GCC ATC GTT TTG CTG-3' and 5'-ACA GGT GAG GTT CAC TGT TTCT -3'; Ill2p35 5'-CTG TGC CTT GGT AGC ATC TAT 
G-3' and 5'-GCA GAG TCT CGC CAT TAT GAT TC-3'; Il23p19 5'-ATG CTG GAT TGC AGA GCA GTA-3' and 5'-ACG GGG CAC ATT ATT TTT AGT CT-3'; Tnfa 5'-GCC TCC CTC TCA TCA GTT CT- ${ }^{\prime}$ and $5^{\prime}$-CAC TTG GTG GTT TGC TAC GA-3'; Il6 5'-GAG GAT ACC ACT CCC AAC AGA CC-3' and 5'-AAG TGC ATC ATC GTT GTT CAT ACA-3'; Illo 5'-GTG GAG CAG GTG AAG AGT GAT TT- ${ }^{\prime}$ ' and 5'-TCC CTG GAT CAG ATT TAG AGA GC-3'; $T g f b 1$ 5'-GCA ACA TGT GGA ACT CTA CCA GA-3' and 5'-GAC GTC AAA AGA CAG CCA CTC A-3'; Cxcll 5'-TGC ACC CAA ACC GAA GTC AT- $3^{\prime}$ and 5'-TTG TCA GAA GCC AGC GTT CAC-3'; Cxcl2 5'-CCA ACC ACC AGG CTA CAG G-3' and 5'-GCG TCA CAC TCA AGC TCT G-3'

\section{Statistics}

Unless otherwise specified, all results are shown as the mean and the SEM. Unpaired Student's $t$ tests, MannWhitney's $U$ tests, or logrank tests were used to statistically analyze the results. Differences were considered significant at $P<0.05$.

\section{Results}

nu/nuIl $1 r^{-1-}$ mice spontaneously develop colitis

To analyze the roles of IL-1 system in innate immunity, we crossed $I l 1 \mathrm{rn}^{-1-}$ mice on BALB/cA background into Foxn $1^{\text {nu/nu }}(n u / n u)$ mice that lack functional thymusderived T cells. These $n u / n u I l 1 r^{-1-}$ mice spontaneously developed severe colitis associated with anorectal prolapse (Fig. 1A). Sixteen mice out of 20 showed anorectal prolapse at 12-weeks of age. Both females and males showed similar symptoms. Colonic wall thickening and shortening of the large intestine were observed in the prolapsed mice (Fig. 1B). Histological analysis revealed mucosal thickening, crypt distortion, and infiltration of a large number of inflammatory cells in the mucosa and submucosa of the large intestine, including the anus, rectum, and colon (Fig. 1C). Infiltration of inflammatory cells was also observed in the colon of non-prolapsed $n u / n u I l 1 r^{-/-}$mice (Fig. 1D), indicating that the spontaneous development of colonic inflammation is a characteristic of $\mathrm{nu} / \mathrm{nuIl} 1 \mathrm{rn}^{-/-}$mice.

\section{Rag2 ${ }^{-1-}$ Ill $\mathrm{rn}^{-/-}$mice spontaneously develop colitis}

Unlike $\alpha \beta$ T cells, $\gamma \delta$ T cells can develop extrathymically in $n u / n u$ mice $[1,27]$. To investigate whether or not extrathymically developed- $\gamma \delta \mathrm{T}$ cells induce colitis in $n u / n u l l 1 r^{-/-}$mice, we crossed $I l 1 r^{-1-}$ mice to Rag2 $2^{-/-}$mice in which $\gamma \delta \mathrm{T}$ cells also do not develop.

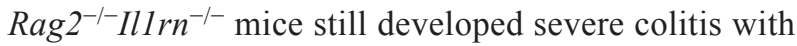
marked colonic shortening and inflammation (Fig. 2A). The signs of colitis, such as diarrhea, bloody stool, perianal mucus excretion, and anorectal prolapse, appeared after 5 -weeks of age, and increased in severity over time (Fig. 2B), with weight loss (Fig. 2C). WT, $I l 1 \mathrm{rn}^{-/-}$, and $\mathrm{Rag}^{2^{-/}}$mice did not show any symptoms of colitis. About half of them succumbed as early as 11-weeks of age (Fig. 2D). These observations suggest that innate immune cells, but not $\gamma \delta \mathrm{T}$ cells, are responsible for the spontaneous development of colitis in $\mathrm{Rag}^{-/-} \mathrm{Ill} \mathrm{rn}^{-/-}$ mice.

IL-17A expression is enhanced in the inflammatory sites of $\mathrm{Rag}^{-/-} \mathrm{Illrn}^{-/-}$mice

Intestinal macrophages produce IL- $1 \beta$ in response to commensal bacteria [29], and IL-1 can induce own IL-1 expression $[5,11]$ that can form a positive feedback loop. To examine the effect of IL-1Ra-deficiency on IL-1 expression in the colon, we analyzed the colonic IL-1 expression in $I l 1 \mathrm{rn}^{-/-}$and $\mathrm{Rag}^{-/-} \mathrm{IlIrn}^{-/-}$mice, and compared with WT and $\operatorname{Rag}^{-/-}$mice, respectively. The expression of $I l 1 \mathrm{a}$ and $I l 1 \mathrm{~b}$ was not changed in $I l 1 \mathrm{rn}^{-/-}$ mice compared to WT mice, indicating that IL-1Ra deficiency pe se does not affect IL-1 production. However, $I l l a$ and $I l l b$ expression were significantly augmented in the perianal tissue of $\mathrm{Rag}^{-/-} \mathrm{IlIrn}^{-/-}$mice (Fig. 3A). Furthermore, $I l 17 a$ and $I l 17 f$ expression as well as $I l 22$ and $I l 6$ expression were also enhanced in $\mathrm{Rag}^{-1-} \mathrm{Ill} \mathrm{rn}^{-1-}$ mice (Fig. 3B). The expression of chemokines, such as Cxcll and $\mathrm{Cxcl} 2$ that induce neutrophil recruitment, was also significantly enhanced in $\mathrm{Rag}^{-/-} \mathrm{Ill} \mathrm{rn}^{-/}$mice (Fig. 3B). The expression of other inflammatory cytokines, including Ifng, Il4, Ill2p35, Il12p40, Il23p19, and Tnfa was not changed in $\mathrm{Rag} 2^{-/-} I l 1 \mathrm{rn}^{-1-}$ mice compared with $\mathrm{Rag}^{-/-}$mice (Fig. 3B). These results indicate that IL1Ra-deficiency-caused excess IL-1 signaling results in the increased IL-17A production in $\mathrm{Rag}^{-/-}{\mathrm{Ill} \mathrm{rn}^{-/}}^{--}$mice.

\section{IL-17A exacerbates colonic inflammation in Rag $2^{-/-}$ Ill $\mathrm{rn}^{-/-}$mice}

To examine whether the increased IL-17A expression in the colon causes the development of colitis in $\mathrm{Rag}^{-/-}$ $I l 1 \mathrm{rn}^{-/}$mice, we have generated $1117 \mathrm{a}^{-/-} \mathrm{Rag}^{-/-} \mathrm{Ill}_{\mathrm{rn}} \mathrm{H}^{--}$ mice by intercrossing $\mathrm{Rag}^{2^{-/}} \mathrm{Il} 1 \mathrm{rn}^{-/-}$mice with $I l 17 \mathrm{a}^{-/-}$ mice. Although the disease signs were not completely 
A
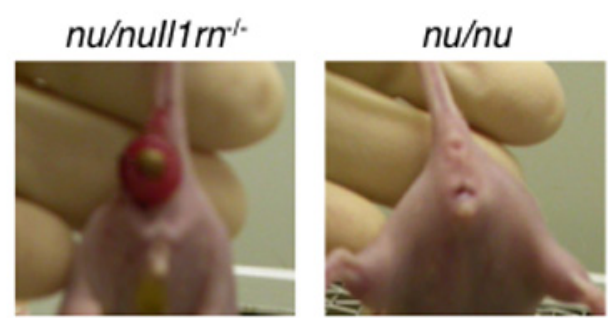

C nu/nu
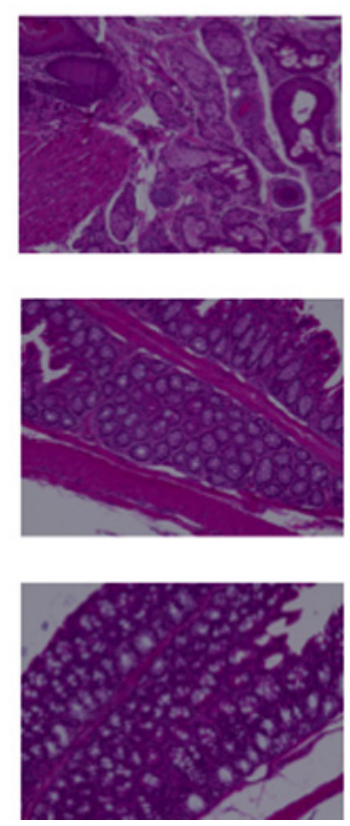

Prolapsed nu/null1 $\mathrm{rn}^{\prime-}$
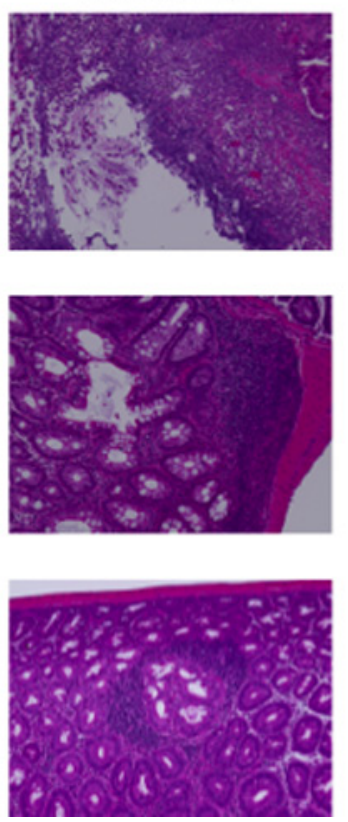

B

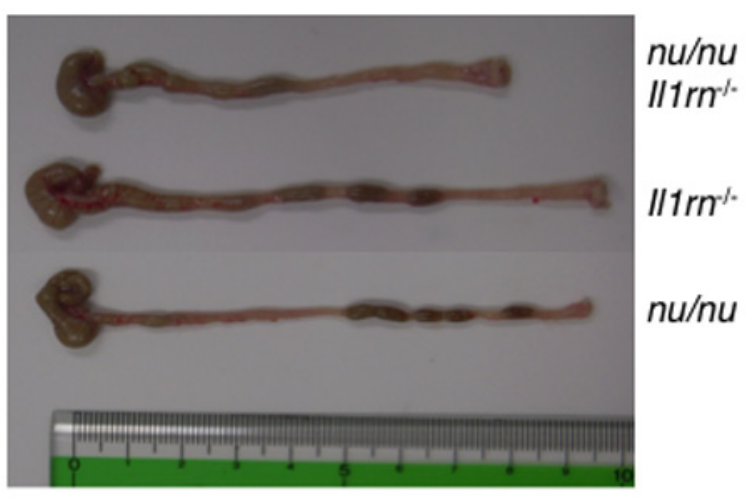

D

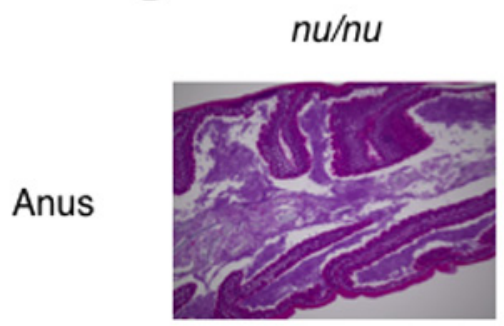

Non-prolapsed nu/null1 $1 \mathrm{rn}^{/ \cdot}$

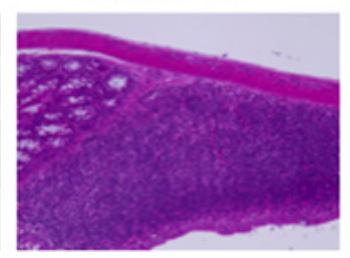

\section{Rectum}

\section{Colon}

Fig. 1. $n u / n u ~ I l 1 r^{-/-}$mice spontaneously develop colitis. (A) Rectal prolapse in $n u / n u I l 1 r n^{-/-}$mouse (left) and control $n u / n u$ mouse (right). (B) Macroscopic analysis of the colon of nu/nu, Ill rn ${ }^{-/}$, and nu/null1rn ${ }^{-/-}$mice. (C) Histological analysis of the colon tissues (anus, rectum, and colon) in $n u / n u$ (left, 20×) and prolapsed nu/nuIll rn ${ }^{-/-}$mouse (right, 20×). (D) Photomicrographs of hematoxylin and eosin stained colon of $n u / n u$ mouse (left) and non-prolapsed $n u / n u I l 1 n^{-/-}$mouse (right). Similar histopathology was observed in another mouse.

disappeared, $I l 17 a^{-1-} \mathrm{Rag}^{-/-} \mathrm{Il} 1 \mathrm{rn}^{-1-}$ female mice significantly restored from weight loss (Fig. 4A) and high mortality (Fig. 4B). We did not determine the effect of the IL-17A-deficiency in the mortality of $\mathrm{Rag}^{-/-} \mathrm{Il} \mathrm{rr}^{-/-}$ male mice. These results suggest that excess IL-17A production exacerbates colitis and promotes mortality in $\mathrm{Rag}^{2^{-/}} \mathrm{Ill} \mathrm{rn}^{-1-}$ mice.
Innate lymphoid cells are major source of IL-17A in the colon of Rag2 $2^{-/-} \mathrm{Ill} \mathrm{rn}^{-/-}$mice

Consistent with local mRNA expression, IL-17Aproducing cells were increased in the colonic lamina propria (cLP) of $\mathrm{Rag}^{-/-} \mathrm{IlI} \mathrm{rn}^{-/-}$mice (Fig. 5A), and the majority of IL-17A-expressing cells were $\mathrm{CD} 4^{-}, \mathrm{CD} 8^{-}$, and $\gamma \delta \mathrm{TCR}^{-}$cell population (Fig. 5B). These cells were also negative for leukocyte lineage marker (Lin) (Fig. 5C), and showed ROR $\gamma \mathrm{t}^{+}$, Sca- $1^{+}$, Thy- $1^{+}, \mathrm{NKp} 46^{-}$, c- 
A

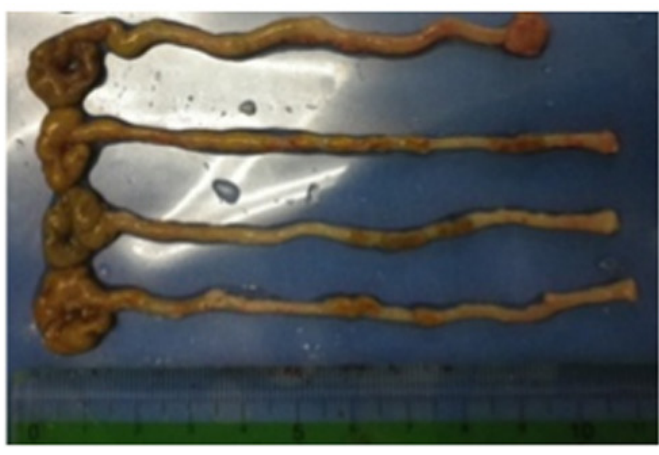

C

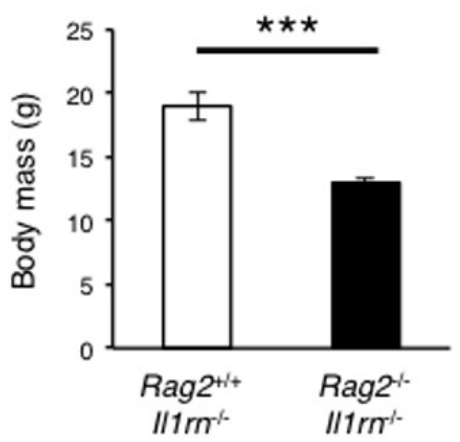

B
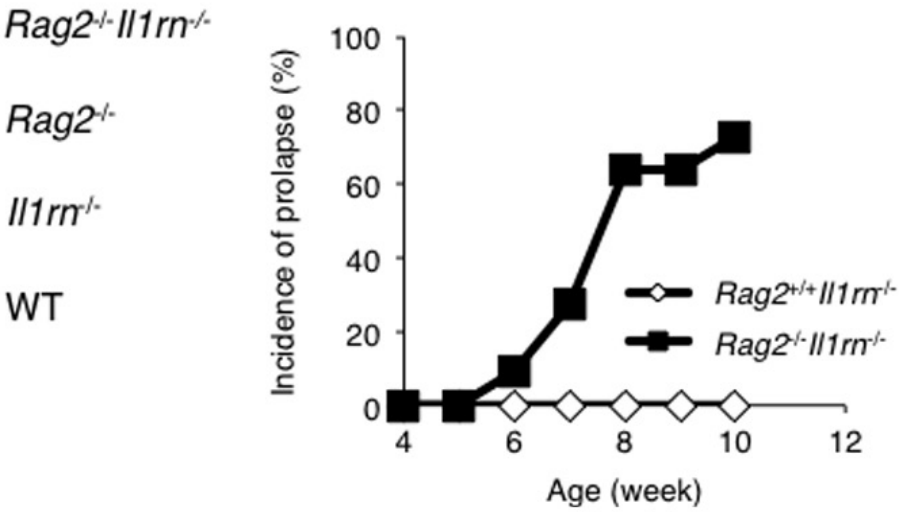

D

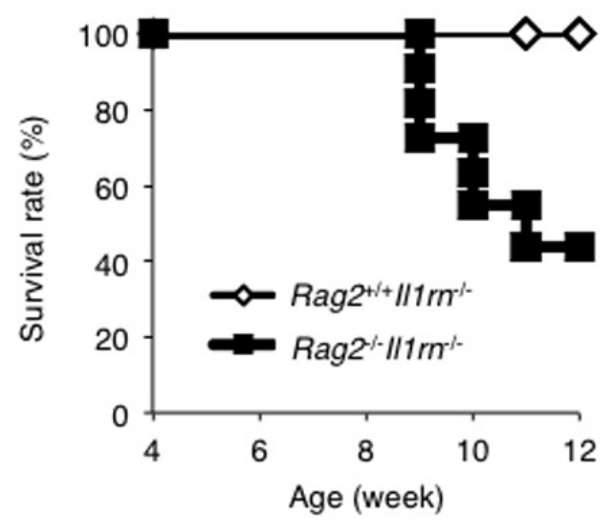

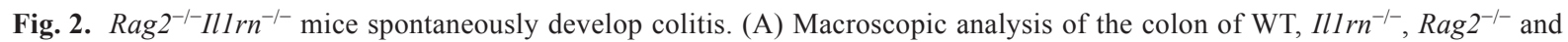
$\mathrm{Rag}^{-/-} I l 1 \mathrm{rn}^{-/-}$mice. (B) Incidence of rectal prolapse of $\mathrm{Rag}^{+/+} I l 1 \mathrm{rn}^{-/-}$(open diamonds, $\mathrm{n}=20$ ), and $\operatorname{Rag}^{2^{-/-}} I l 1 \mathrm{rn}^{-/-}$mice (filled squares, $\mathrm{n}=11)$. (C) Body weight of $\mathrm{Rag}^{+/+} I l 1 \mathrm{rn}^{-/-}\left(\mathrm{n}=8\right.$, female) and $\mathrm{Rag}^{-/-} I l 1 \mathrm{rn}^{-/-}$mice $(\mathrm{n}=9$, female) at 8-weeks of age. (D) Survival rate of $\mathrm{Rag}^{+/+} I l 1 \mathrm{rn}^{-/-}$(open diamonds, $\mathrm{n}=20$ ) and $\mathrm{Rag}^{-/-} I l 1 \mathrm{rn}^{-/-}$mice (filled squares, $\mathrm{n}=11$ ). Data are representative of two independent experiments.

kit $^{-}$phenotype (Fig. 5D), consistent with the characteristics of ILC3s [2]. These findings suggest that ILC3s are responsible for the increased IL-17A production in $\mathrm{Rag}^{-/-} \mathrm{Ill} \mathrm{rn}^{-/-}$mice.

Absence of Treg cells and expansion of ILC3s cause

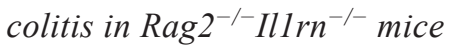

IL- $1 \beta$ is crucial for intestinal IL-17A production in both innate and adaptive immune cells [29, 31]. Consistent with this, colonic IL-17A expression was increased in $I l 1 \mathrm{rn}^{-/-}$immunocompetent mice compared with WT mice (Fig. 3B, Fig. 5A and 5B). The majority of IL-17A producers in cLP was $\gamma \delta \mathrm{T}$ cells, and Th17 and CD4 ${ }^{-}$ $\mathrm{CD}^{-} \gamma \delta \mathrm{TCR}^{-}$cells also produced IL-17A. However, these $111 \mathrm{rn}^{-/-}$mice did not develop colitis, suggesting that the IL-17A levels were not enough to induce colitis or some suppressor cells might suppress the development of colitis, or both.

Then, we examined Treg cells in these mice. $\mathrm{CD} 4^{+} \mathrm{Foxp}^{+}$Treg cells were greatly increased in cLP of $I l 1 \mathrm{rn}^{-/-}$mice compared with that of WT mice (Fig. 6A and 6B). On the other hand, no Foxp $3^{+}$cells were found

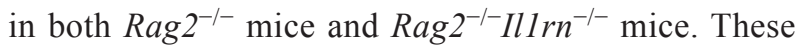
results suggested that Treg cells suppress the development of colitis in $I l 1 \mathrm{rn}^{-/-}$mice. Although Treg cell-derived immunosuppressive cytokines, such as IL-10 and TGF- $\beta$, can mediate the suppression of wide range of immune responses and prevent experimental colitis [18], no significant increase of these cytokines was observed in both $\mathrm{IlIrn}^{-/-}$and $I l 1 \mathrm{rn}^{-1-} \mathrm{Rag}^{-/-}$mice (Fig. 6C), and Treg cells in $\mathrm{IlIrn}^{-/-}$mice did not express IL-10 (Fig. 6A). Instead, the ILC3 components that express both 
A

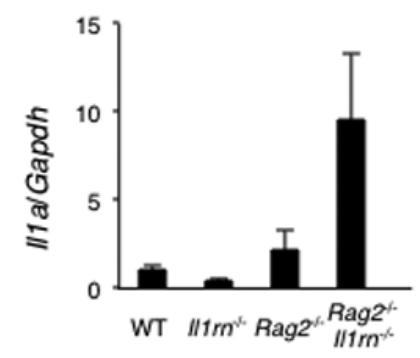

B
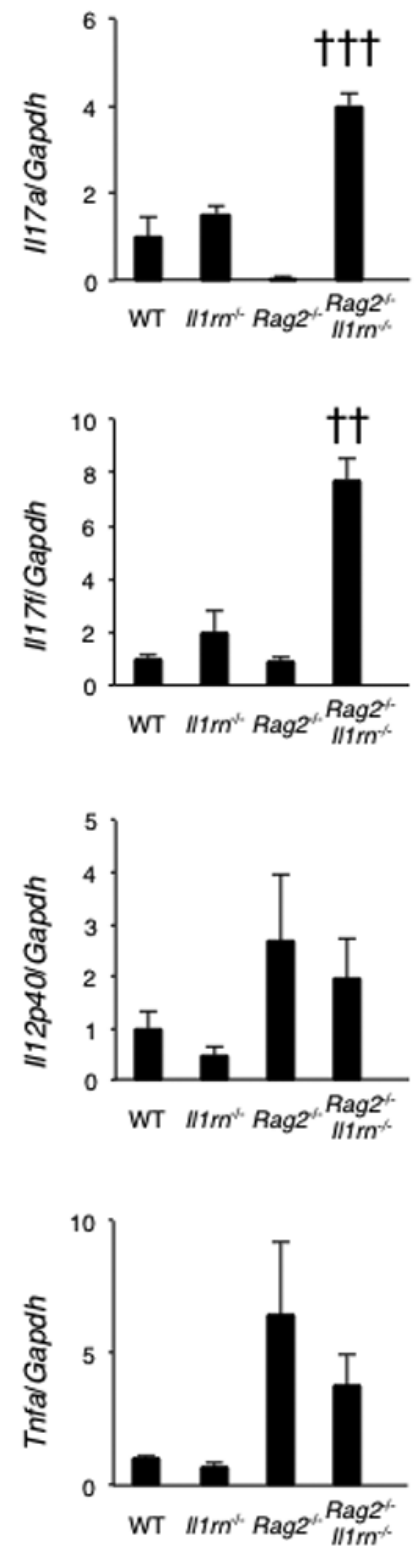
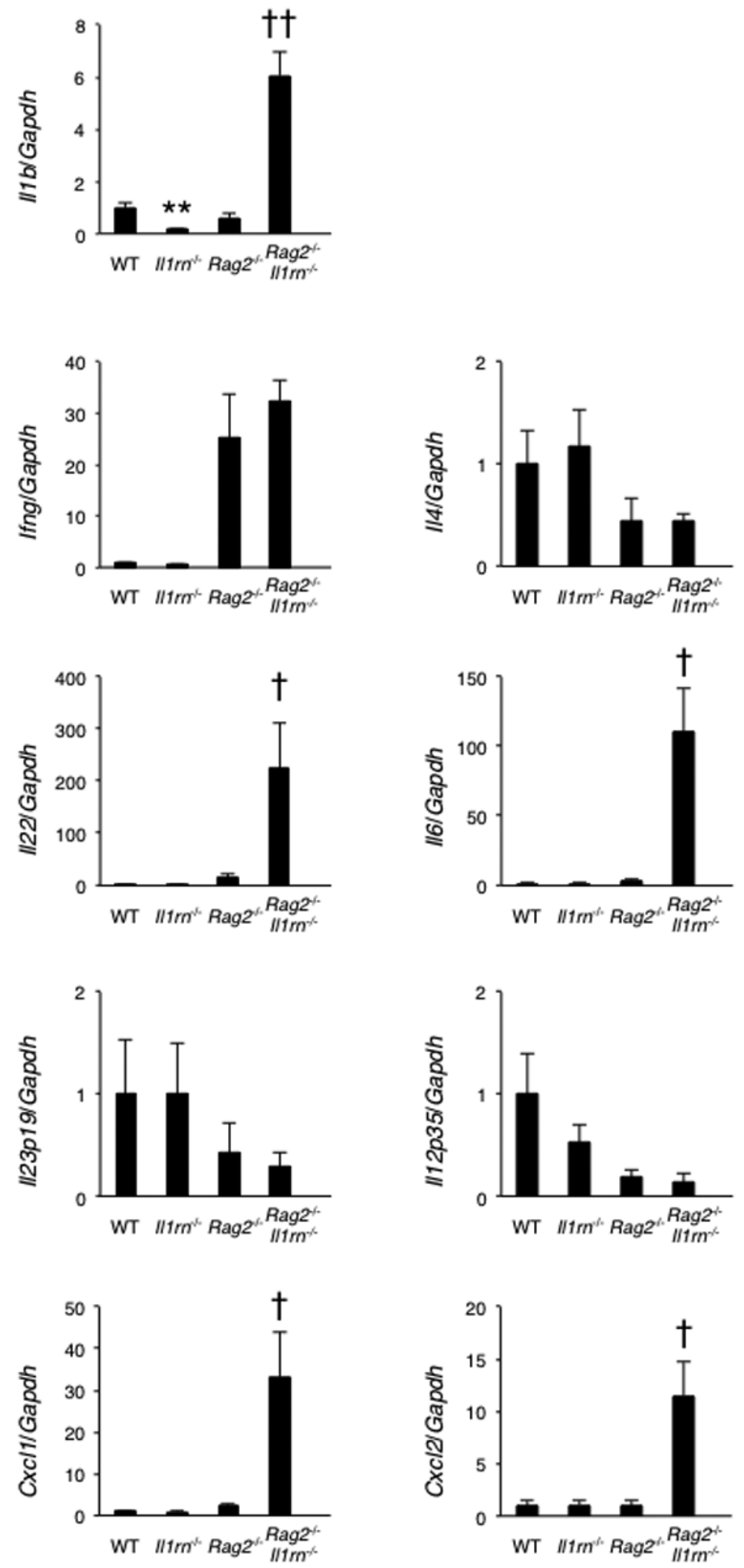

Fig. 3. IL-17A expression is enhanced in the inflammatory sites of Rag $^{-/-} I l 1 \mathrm{rn}^{-/-}$mice. (A and B) The expression of mRNAs for IL-1 $\alpha$ and IL-1 $\beta$ (A), and IFN- $\gamma$, IL-4, IL-17F, IL-22, IL-6, IL-12p40, IL-12p35, IL-23p19. TNF- $\alpha$, CXCL1, and CXCL2 (B), in the perianal tissue of WT, Ill rn ${ }^{-/}$, $\operatorname{Rag}^{-{ }^{--}}$, and $\mathrm{Rag}^{-/-} I l 1 \mathrm{rn}^{-/}$mice. Data are normalized to GAPDH in perianal tissue ( 3 to 4 mice per each group) and shown as mean \pm SEM. **: $P<0.01$ vs. WT mice,

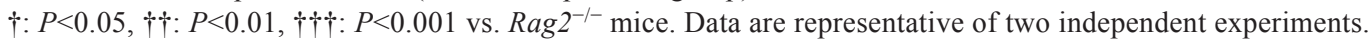


A

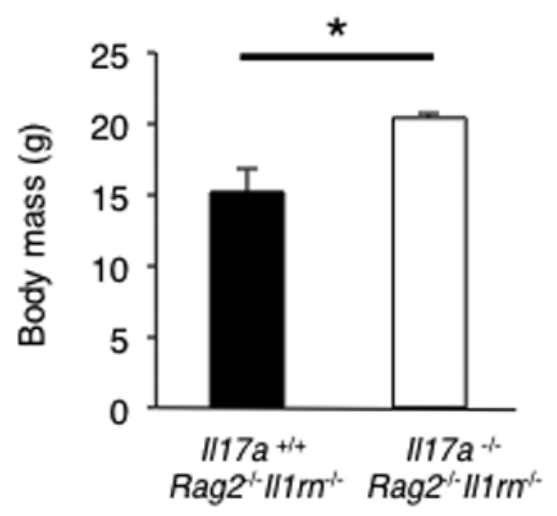

B

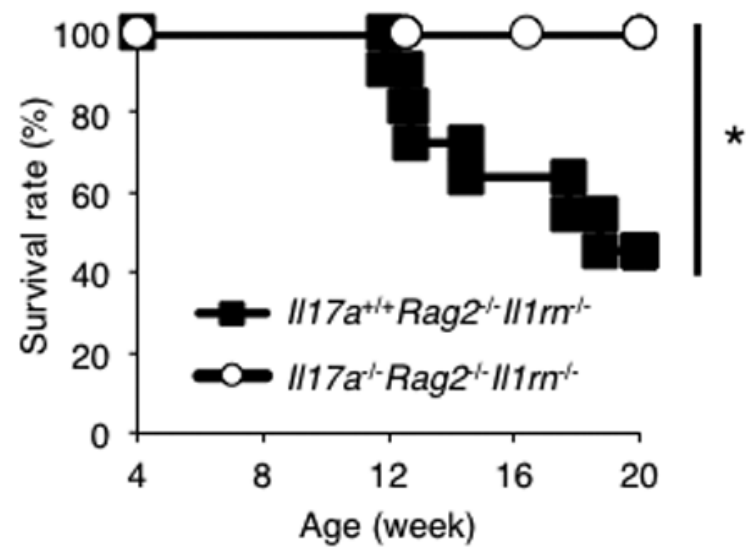

Fig. 4. IL-17A exacerbates colonic inflammation in $\operatorname{Rag}^{-/-} I l 1 \mathrm{rn}^{-/-}$mice. (A) Body weight of $I l 17 \mathrm{a}^{+/+} \mathrm{Rag}^{-/-} I l 1 \mathrm{rn}{ }^{-/-}(\mathrm{n}=4$, female) and $I l 17 a^{-/-} \mathrm{Rag}^{-/-} I l 1 \mathrm{rn}^{-/-}$mice $(\mathrm{n}=4$, female) at 10-weeks of age. Data are shown as mean \pm SEM. (B) Survival rate of $I l 17 a^{+/+} R_{a g} 2^{-/-} I l 1 r^{-/-}$(closed squares, $\mathrm{n}=10$, female) and $I l 17 a^{-/-} \mathrm{Rag}^{-/-} I l 1 \mathrm{rn}^{-/-}$mice (opened circles, $\mathrm{n}=8$, female). *, $P<0.05$.

Thy 1.2 and Sca-1 were robustly increased in cLP of Rag2 ${ }^{-/-}$and Rag $^{-/-} I l 1 \mathrm{rn}^{-/-}$mice (Fig. 6D). IL-1 Ra expression in $\mathrm{Rag}^{-/-}$mice was similar to that in WT mice (Fig. 6E), suggesting that the increase of ILC3 population in $\mathrm{Rag} 2^{-/-}$mice is independent of IL-1 systems. These results suggest that both the expansion of IL-17Aproducing ILC3s and the absence of Treg cells in Rag $2^{-/}$ $1 \mathrm{ll} \mathrm{rn}^{-1-}$ mice are responsible for the development of colitis in these mice.

\section{Discussion}

In this study, we showed that IL-1Ra-deficiency in $n u /$ $n u$ mice as well as in $R a g 2^{-/-}$mice results in the development of spontaneous colitis. In $\mathrm{Rag}^{-/-} \mathrm{IlI}_{\mathrm{rn}} \mathrm{H}^{-/-}$mice, IL-17A-producing ILC3s were increased in colonic LP and IL-17A deficiency recovered their mortality, suggesting that IL-17A-producing ILC3s are responsible for the exacerbation of colitis in these mice.

Recent studies have suggested the importance of innate immune cells in the pathogenesis of colitis. $\gamma \delta \mathrm{T}$ cells drive intestinal inflammation in both innate and $\mathrm{T}$ cell-induced colitis $[6,23,25]$, and activated $\gamma \delta$ T cells are increased in the intestinal tissue in IBD patients [20, $36]$. Thus, we first thought that $\gamma \delta \mathrm{T}$ cells might be important for the development of colitis in $\mathrm{nu} / \mathrm{null}_{\mathrm{rn}} \mathrm{r}^{-1}$ mice. However, the severe colitis was also developed in $\mathrm{Rag}^{-/-} \mathrm{Il}_{1 \mathrm{rn}^{-/-}}$mice, indicating that colitis develops without $\gamma \delta \mathrm{T}$ cells at least in $\mathrm{Rag} 2^{-/-} I l 1 \mathrm{rn}^{-/-}$mice, although this does not necessarily exclude the possibility that $\gamma \delta \mathrm{T}$ cells are involved in the development of colitis in $n u / n u I l 1 r^{-/-}$mice. In Rag2 $2^{-1-} I l 1 r^{-/-}$mice, IL-17A production was enhanced in inflamed tissues, and the majority of colonic IL-17A was produced by ILC3s. These colitogenic ILC3s previously found in two colitis mouse models: H. hepaticus-infected 129SvEvRag2 $2^{-/}$ mice [2] and $T b \times 21^{-1-}$ Rag2 $^{--}$mice [26]. Elevated IL17A mRNA expression is also observed in the intestinal $\mathrm{CD}^{-}$ CD56- innate lymphoid cells of IBD patients [9].

IL-1 $\beta$ is crucial for the activation of intestinal IL-17Aproducing cells. Recent studies have shown that commensal bacteria specifically induce IL- $1 \beta$ in LP macrophages [29], and induce IL-1R expression on IL-17A-producing $\gamma \delta \mathrm{T}$ cells [7]. Importantly, innate immune cells can produce IL-17A by the action of IL-1 $\beta$ and IL-23 without TCR signaling. Indeed, IL-17Aproducing cells, which consist of mostly $\gamma \delta \mathrm{T}$ cells and small proportions of Th17 cells and ILC3s, were increased in $I l 1 \mathrm{rn}^{-/-}$mice compared to WT mice even without inflammation. We found that ILC3s are the major IL-17A producer in $\mathrm{Rag}^{-/-} \mathrm{Il}_{1 \mathrm{rn}} \mathrm{H}^{-/-}$mice, in which Th17 and $\gamma \delta \mathrm{T}$ cells are absent, and IL-17A-deficiency can significantly prolong their survival. Thus, these observations suggest that excess IL-1 $\beta$-induced ILC3-derived IL-17A participates in the development of colitis in $\mathrm{Rag}^{-/-} \mathrm{Ill} \mathrm{rn}^{-/-}$mice. However, because IL-17Adeficiency did not completely suppress the development of colitis although it extended survival, IL-17A is not the principal mediator of the inflammation. Probably, excess IL-1 $\beta$ signaling itself causes inflammation in the 
A

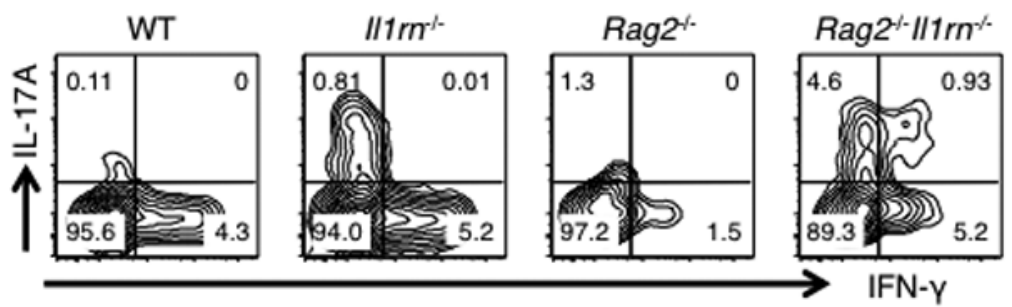

B
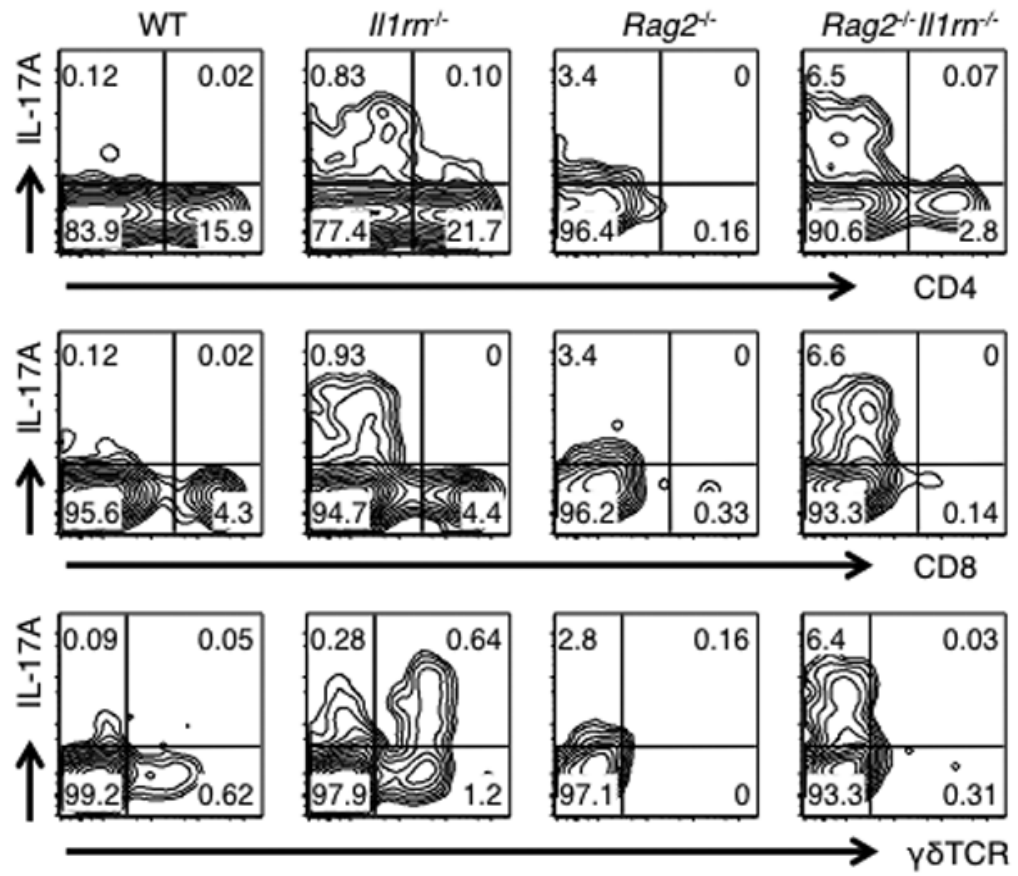

C

D
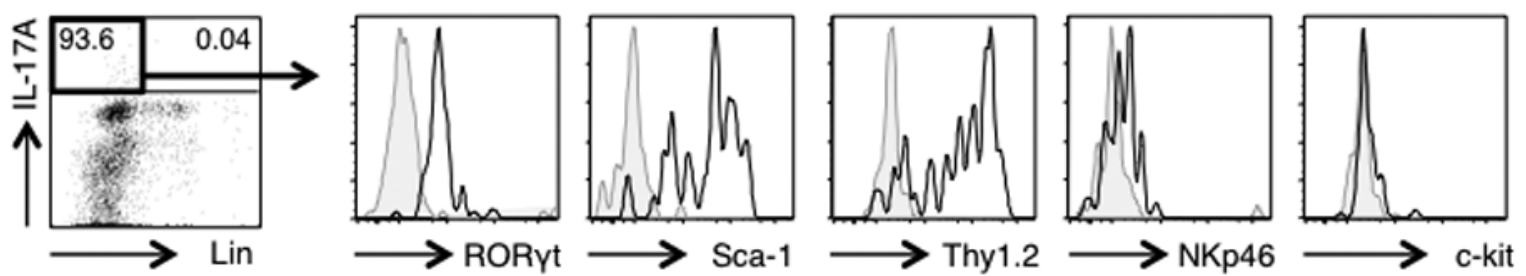

Fig. 5. Innate lymphoid cells are major source of IL-17A in the colon of $R a g 2^{-/} I l 1 r^{-/-}$mice. (A and B) IL-17A- and IFN- $\gamma$ expressing cells in colonic lamina propria (cLP) of WT, $I l 1 \mathrm{rn}^{-/-}, \mathrm{Rag}^{-/-}$, and $\mathrm{Rag}^{-1-} \mathrm{IlIrn}^{-/-}$mice were analyzed by FACS. Isolated cLP cells were stimulated with PMA and ionomycin for $5 \mathrm{~h}$ and stained for intracellular IL-17A and IFN- $\gamma$. All live

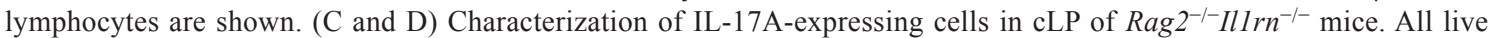
lymphocytes are shown. Cells were stained by the mixture of antibodies against lymphocyte lineage markers (Lin: CD4, CD8, $\gamma \delta$ TCR, CD11b, CD11c, Gr-1, and B220) and intracellular IL-17A. Numbers refer to percent cells in IL-17 $7^{+}$cells (C). $\mathrm{Lin}^{-} \mathrm{IL}-17 \mathrm{~A}^{+}$cells were stained by specific antibodies (black line) and isotype controls (gray line) (D). Data are representative of two independent experiments.

intestine in an autoinflammatory manner, and IL-17A exacerbates the disease.

Treg cells are one of important regulatory cells in the immune system [17], and can suppress $\gamma \delta$ T cell-derived IL-17A-induced intestinal inflammation [25, 37]. We found that IL-17A-producing ILC3s are increased in
$\mathrm{Rag}^{-1-} \mathrm{Il} 1 \mathrm{rn}^{-1-}$ mice compared with $I l 1 \mathrm{rn}^{-/-}$mice, cor-

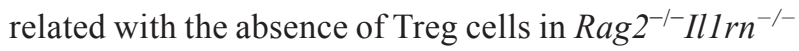
mice. These observations suggest that Treg cells suppress IL-17A production and/or differentiation of ILC3s in $I l 1 \mathrm{rn}^{-/-}$mice. Treg cells may also suppress the development of colitis in $I l 1 \mathrm{rn}^{-/-}$mice in which relatively large 
A

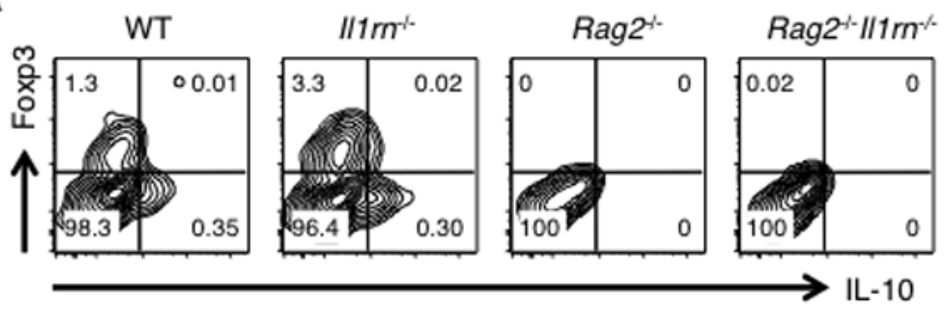

$\mathrm{B}$
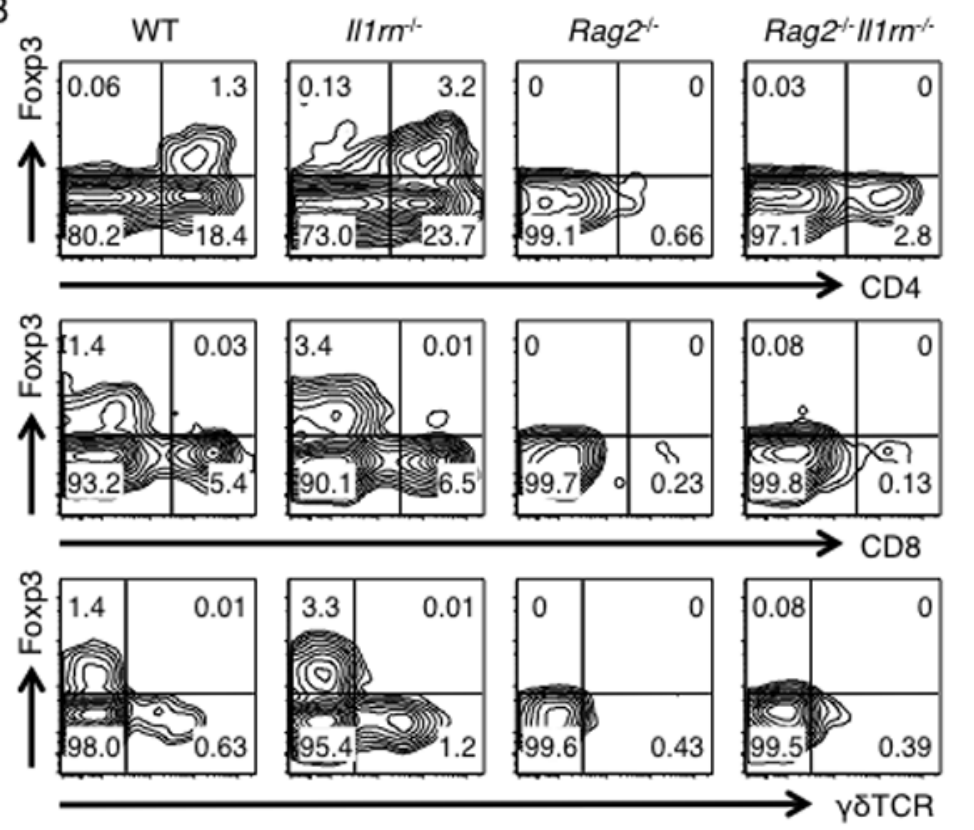

C
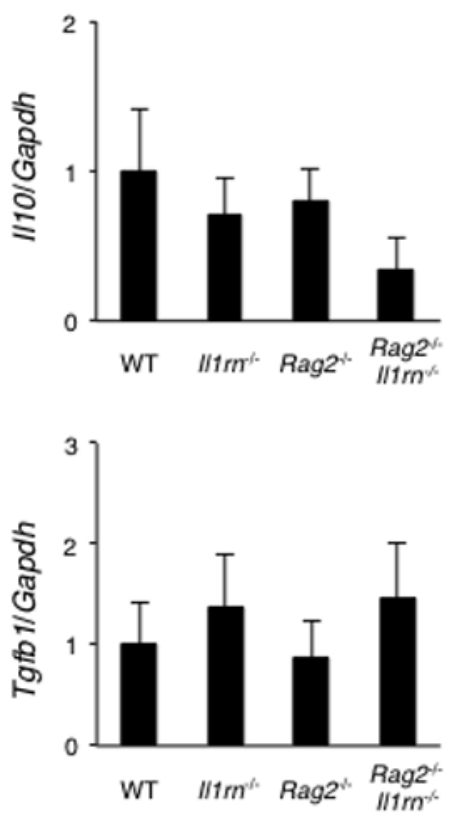

E

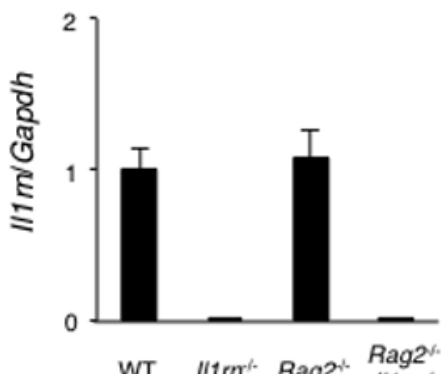

D

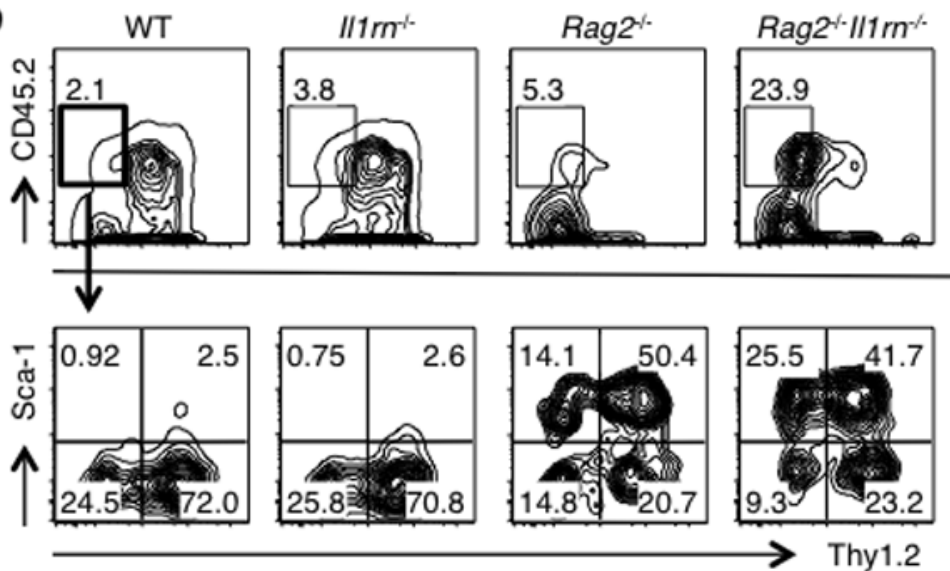

Fig. 6. Absence of Treg cells and expansion of ILC3s cause colitis in $\operatorname{Rag}^{-/-} I l 1 \mathrm{rn}^{-/-}$mice. (A and B) Foxp3- and IL-10-expressing

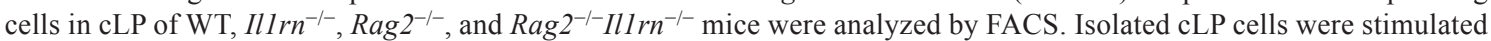
with PMA and ionomycin for $5 \mathrm{~h}$ and stained for intracellular IL-10 and intranuclear Foxp3. All live lymphocytes are shown. (C and E) mRNA expressions of IL-10 and TGF- $\beta(C)$, and secretion form of IL-1Ra (E) in the perianal tissue of WT, Ill r ${ }^{-/-}$, $\mathrm{Rag}^{2^{--}}$, and $\mathrm{Rag}^{-/-} \mathrm{IlI} \mathrm{rn}^{-/}$mice. Data are normalized to GAPDH in the perianal tissue (3 to 4 mice per each group) and

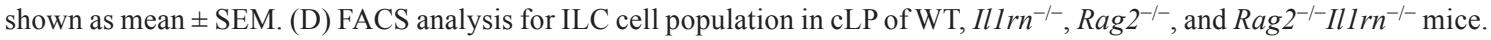
All live lymphocytes (top) and $\mathrm{Lin}^{-} \mathrm{CD} 45.2^{+}$cells are shown (bottom). Data are representative of two independent experiments. 
number of IL-17 producers is detected. Because recent studies suggested that $\mathrm{CD} 4^{+} \mathrm{T}$ cells and ILCs mutually regulate their activity by competing for a cytokine niche [28], it is possible that the expansion of ILC3s in $\mathrm{Rag}^{2^{-/-}}$ Ill $\mathrm{rn}^{-/-}$mice is caused by the loss of competition with neighboring Th17 cells for limited spaces and resources and not the defect of suppression by Treg cells.

In summary, we showed that excess IL-1 signalinginduced IL-17A production from expanded ILC3s and the absence of Treg cells promote the spontaneous development of colitis in $\mathrm{Rag}^{-/-} \mathrm{Ill} \mathrm{rn}^{-/-}$mice, suggesting the importance of the balance between IL-17A-producing cells and Treg cells in the regulation of intestinal immune homeostasis. $111 \mathrm{rn}^{-1-}$ mice are unique because these mice spontaneously develop autoimmune arthritis and aortitis and also develop autoinflammatory skin lesions. In this report, we have further demonstrated that this strain is also useful as a colitis model in which innate immune cells play a critical role.

\section{Acknowledgments}

We thank Dr. Sakaguchi (Osaka University, Japan) for providing $\mathrm{Rag}^{-/-}$mice. This work was supported by CREST (Y. I.), Grants-in-Aid from the Ministry of Education, Culture, Sports, Science and Technology of Japan (Y. I.), the Promotion of Basic Research Activities for Innovative Biosciences (Y. I.), and JSPS (A. A.). The authors declare no conflicts of interest.

\section{References}

1. Bandeira, A., Mota-Santos, T., Itohara, S., Degermann, S., Heusser, C., Tonegawa, S., and Coutinho, A. 1990. Localization of gamma/delta $\mathrm{T}$ cells to the intestinal epithelium is independent of normal microbial colonization. J. Exp. Med. 172: 239-244. [Medline] [CrossRef]

2. Buonocore, S., Ahern, P.P., Uhlig, H.H., Ivanov, I.I., Littman, D.R., Maloy, K.J., and Powrie, F. 2010. Innate lymphoid cells drive interleukin-23-dependent innate intestinal pathology. Nature 464: 1371-1375. [Medline] [CrossRef]

3. Coccia, M., Harrison, O.J., Schiering, C., Asquith, M.J., Becher, B., Powrie, F., and Maloy, K.J. 2012. IL-1 $\beta$ mediates chronic intestinal inflammation by promoting the accumulation of IL-17A secreting innate lymphoid cells and CD4(+) Th17 cells. J. Exp. Med. 209: 1595-1609. [Medline] [CrossRef]

4. Cua, D.J. and Tato, C.M. 2010. Innate IL-17-producing cells: the sentinels of the immune system. Nat. Rev. Immunol. 10: 479-489. [Medline] [CrossRef]

5. Dinarello, C.A., Ikejima, T., Warner, S.J., Orencole, S.F.,
Lonnemann, G., Cannon, J.G., and Libby, P. 1987. Interleukin 1 induces interleukin 1. I. Induction of circulating interleukin 1 in rabbits in vivo and in human mononuclear cells in vitro. J. Immunol. 139: 1902-1910. [Medline]

6. Do, J.S., Visperas, A., Dong, C., Baldwin, W.M. 3rd., and Min, B. 2011. Cutting edge: Generation of colitogenic Th17 CD4 T cells is enhanced by $\mathrm{IL}-17^{+} \gamma \delta \mathrm{T}$ cells. J. Immunol. 186: 4546-4550. [Medline] [CrossRef]

7. Duan, J., Chung, H., Troy, E., and Kasper, D.L. 2010. Microbial colonization drives expansion of IL-1 receptor 1-expressing and IL-17-producing gamma/delta T cells. Cell Host. Microbe. 7: 140-150. [Medline] [CrossRef]

8. Fujino, S., Andoh, A., Bamba, S., Ogawa, A., Hata, K., Araki, Y., Bamba, T., and Fujiyama, Y. 2003. Increased expression of interleukin 17 in inflammatory bowel disease. Gut 52: 65-70. [Medline] [CrossRef]

9. Geremia, A., Arancibia-Cárcamo, C.V., Fleming, M.P.P., Rust, N., Singh, B., Mortensen, N.J., Travis, S.P.L., and Powrie, F. 2011. IL-23-responsive innate lymphoid cells are increased in inflammatory bowel disease. J. Exp. Med. 208: 1127-1133. [Medline] [CrossRef]

10. Hirota, K., Hashimoto, M., Yoshitomi, H., Tanaka, S., Nomura, T., Yamaguchi, T., Iwakura, Y., Sakaguchi, N., and Sakaguchi, S. 2007. T cell self-reactivity forms a cytokine milieu for spontaneous development of IL-17+ Th cells that cause autoimmune arthritis. J. Exp. Med. 204: 41-47. [Medline] [CrossRef]

11. Horai, R., Asano, M., Sudo, K., Kanuka, H., Suzuki, M., Nishihara, M., Takahashi, M., and Iwakura, Y. 1998. Production of mice deficient in genes for interleukin (IL)-1alpha, IL-1beta, IL-1alpha/beta, and IL-1 receptor antagonist shows that IL-1beta is crucial in turpentine-induced fever development and glucocorticoid secretion. J. Exp. Med. 187: 1463-1475. [Medline] [CrossRef]

12. Horai, R., Nakajima, A., Habiro, K., Kotani, M., Nakae, S., Matsuki, T., Nambu, A., Saijo, S., Kotaki, H., Sudo, K., Okahara, A., Tanioka, H., Ikuse, T., Ishii, N., Schwartzberg, P.L., Abe, R., and Iwakura, Y. 2004. TNF-alpha is crucial for the development of autoimmune arthritis in IL-1 receptor antagonist-deficient mice. J. Clin. Invest. 114: 1603-1611. [Medline]

13. Horai, R., Saijo, S., Tanioka, H., Nakae, S., Sudo, K., Okahara, A., Ikuse, T., Asano, M., and Iwakura, Y. 2000. Development of chronic inflammatory arthropathy resembling rheumatoid arthritis in interleukin 1 receptor antagonist-deficient mice. J. Exp. Med. 191: 313-320. [Medline] [CrossRef]

14. Iwakura, Y., Ishigame, H., Saijo, S., and Nakae, S. 2011. Functional specialization of interleukin-17 family members. Immunity 34: 149-162. [Medline] [CrossRef]

15. Khor, B., Gardet, A., and Xavier, R.J. 2011. Genetics and pathogenesis of inflammatory bowel disease. Nature 474: 307-317. [Medline] [CrossRef]

16. Komiyama, Y., Nakae, S., Matsuki, T., Nambu, A., Ishigame, H., Kakuta, S., Sudo, K., and Iwakura, Y. 2006. IL-17 plays an important role in the development of experimental autoimmune encephalomyelitis. J. Immunol. 177: 566-573. [Medline]

17. Littman, D.R. and Rudensky, A.Y. 2010. Th17 and regula- 
tory $\mathrm{T}$ cells in mediating and restraining inflammation. Cell 140: 845-858. [Medline] [CrossRef]

18. Maloy, K.J., Salaun, L., Cahill, R., Dougan, G., Saunders, N.J., and Powrie, F. 2003. CD4+CD25+ T(R) cells suppress innate immune pathology through cytokine-dependent mechanisms. J. Exp. Med. 197: 111-119. [Medline] [CrossRef]

19. Matsuki, T., Isoda, K., Horai, R., Nakajima, A., Aizawa, Y., Suzuki, K., Ohsuzu, F., and Iwakura, Y. 2005. Involvement of tumor necrosis factor-alpha in the development of T celldependent aortitis in interleukin-1 receptor antagonist-deficient mice. Circulation 112: 1323-1331. [Medline] [CrossRef]

20. McVay, L.D., Li, B., Biancaniello, R., Creighton, M.A., Bachwich, D., Lichtenstein, G., Rombeau, J.L., and Carding, S.R. 1997. Changes in human mucosal gamma delta T cell repertoire and function associated with the disease process in inflammatory bowel disease. Mol. Med. 3: 183-203. [Medline]

21. Nakae, S., Saijo, S., Horai, R., Sudo, K., Mori, S., and Iwakura, Y. 2003. IL-17 production from activated T cells is required for the spontaneous development of destructive arthritis in mice deficient in IL-1 receptor antagonist. Proc Natl. Acad. Sci. USA 100: 5986-5990. [Medline] [CrossRef]

22. Nakajima, A., Matsuki, T., Komine, M., Asahina, A., Horai, R., Nakae, S., Ishigame, H., Kakuta, S., Saijo, S., and Iwakura, Y. 2010. TNF, but not IL-6 and IL-17, is crucial for the development of T cell-independent psoriasis-like dermatitis in Il1 rn-/- mice. J. Immunol. 185: 1887-1893. [Medline] [CrossRef]

23. Nanno, M., Kanari, Y., Naito, T., Inoue, N., Hisamatsu, T., Chinen, H., Sugimoto, K., Shimomura, Y., Yamagishi, H., Shiohara, T., Ueha, S., Matsushima, K., Suematsu, M., Mizoguchi, A., Hibi, T., Bhan, A.K., and Ishikawa, H. 2008. Exacerbating role of gammadelta $\mathrm{T}$ cells in chronic colitis of T-cell receptor alpha mutant mice. Gastroenterology 134: 481-490. [Medline] [CrossRef]

24. O'Connor, W. Jr., Kamanaka, M., Booth, C.J., Town, T., Nakae, S., Iwakura, Y., Kolls, J.K., and Flavell, R.A. 2009. A protective function for interleukin 17A in T cell-mediated intestinal inflammation. Nat. Immunol. 10: 603-609. [Medline] [CrossRef]

25. Park, S.G., Mathur, R., Long, M., Hosh, N., Hao, L., Hayden, M.S., and Ghosh, S. 2010. T regulatory cells maintain intestinal homeostasis by suppressing $\gamma \delta \mathrm{T}$ cells. Immunity 33: 791-803. [Medline] [CrossRef]

26. Powell, N., Walker, A.W., Stolarczyk, E., Canavan, J.B., Gökmen, M.R., Marks, E., Jackson, I., Hashim, A., Curtis, M.A., Jenner, R.G., Howard, J.K., Parkhill, J., MacDonald, T.T., and Lord, G.M. 2012. The transcription factor T-bet regulates intestinal inflammation mediated by interleukin-7 receptor+ innate lymphoid cells. Immunity 37: 674-684.
[Medline] [CrossRef]

27. Saito, H., Kanamori, Y., Takemori, T., Nariuchi, H., Kubota, E., Takahashi-Iwanaga, H., Iwanaga, T., and Ishikawa, H. 1998. Generation of intestinal T cells from progenitors residing in gut cryptopatches. Science 280: 275-278. [Medline] [CrossRef]

28. Sawa, S., Lochner, M., Satoh-Takayama, N., Dulauroy, S., Bérard, M., Kleinschek, M., Cua, D., Di Santo, J.P., and Eberl, G. 2011. ROR $\gamma \mathrm{t}+$ innate lymphoid cells regulate intestinal homeostasis by integrating negative signals from the symbiotic microbiota. Nat. Immunol. 12: 320-326. [Medline] [CrossRef]

29. Shaw, M.H., Kamada, N., Kim, Y.G., and Núñez, G. 2012. Microbiota-induced IL-1 $\beta$, but not IL-6, is critical for the development of steady-state TH17 cells in the intestine. J. Exp. Med. 209: 251-258. [Medline] [CrossRef]

30. Spits, H., Artis, D., Colonna, M., Diefenbach, A., Di Santo, J.P., Eberl, G., Koyasu, S., Locksley, R.M., McKenzie, A.N.J., Mebius, R.E., Powrie, F., and Vivier, E. 2013. Innate lymphoid cells - a proposal for uniform nomenclature. Nat. Rev. Immunol. 13: 145-149. [Medline] [CrossRef]

31. Sutton, C.E., Lalor, S.J., Sweeney, C.M., Brereton, C.F., Lavelle, E.C., and Mills, K.H.G. 2009. Interleukin-1 and IL23 induce innate IL-17 production from gammadelta T cells, amplifying Th17 responses and autoimmunity. Immunity 31: 331-341. [Medline] [CrossRef]

32. Sutton, C.E., Mielke, L.A., and Mills, K.H.G. 2012. IL17-producing $\gamma \delta \mathrm{T}$ cells and innate lymphoid cells. Eur. $J$. Immunol .42: 2221-2231. [Medline] [CrossRef]

33. Uhlig, H.H., McKenzie, B.S., Hue, S., Thompson, C., JoyceShaikh, B., Stepankova, R., Robinson, N., Buonocore, S., Tlaskalova-Hogenova, H., Cua, D.J., and Powrie, F. 2006. Differential activity of IL-12 and IL-23 in mucosal and systemic innate immune pathology. Immunity 25: 309-318. [Medline] [CrossRef]

34. Weigmann, B., Tubbe, I., Seidel, D., Nicolaev, A., Becker, C., and Neurath, M.F. 2007. Isolation and subsequent analysis of murine lamina propria mononuclear cells from colonic tissue. Nat. Protoc. 2: 2307-2311. [Medline] [CrossRef]

35. Xavier, R.J. and Podolsky, D.K. 2007. Unravelling the pathogenesis of inflammatory bowel disease. Nature 448: 427-434. [Medline] [CrossRef]

36. Yeung, M.M., Melgar, S., Baranov, V., Öberg, A., Danielsson, A., Hammarström, S., and Hammarström, M.L. 2000. Characterisation of mucosal lymphoid aggregates in ulcerative colitis: immune cell phenotype and TcR-gammadelta expression. Gut 47: 215-227. [Medline] [CrossRef]

37. Yurchenko, E., Levings, M.K., and Piccirillo, C.A. 2011. CD4+ Foxp3+ regulatory T cells suppress $\gamma \delta$ T-cell effector functions in a model of T-cell-induced mucosal inflammation. Eur. J. Immunol. 41: 3455-3466. [Medline] [CrossRef] 